\title{
The Spirit of Laws is Not Universal: Alternatives to the Enforcement Paradigm for Human Rights
}

\author{
Abdullahi Ahmed An-Na'im \\ Charles Howard Candler Professor of Law, Emory University School of Law, \\ Atlanta \\ aannaim@emory.edu
}

\begin{abstract}
Drawing on the contested legacy of Montesquieu in The Spirit of the Laws, this essay questions the efficacy of state-centric legality in the enforcement of human rights, and proposes an alternative approach of cultural transformation and political mobilization. The author begins by exploring whether Montesquieu's thought may have inspired European powers to seek to impose his model of the nation-state and its positive laws through global colonial projects. Second, the author discusses the structural inadequacy of the current treaty-based state-centric enforcement paradigm while highlighting the viability of a universally realistic alternative of cultural transformation and political mobilization for the implementation of consensus-based human rights norms. Third, the author explores his proposed people-centered alternative to the state-centric enforcement model for human rights. This paradigm shift is necessary because the current legalistic approach has totally failed in providing any protection of human rights for the vast majority of humanity around the world.
\end{abstract}

\section{Keywords}

Legacy of Montesquieu - universality of human rights - international law enforcement of human rights - cultural and political - implementation

The essential quality of the universality of human rights may be explained in terms of what I call the three "Cs", namely, the concept, content and context of

(C) AN-NA'IM, 2016 | DOI 10.1163/22112596-02102008

This is an open access article distributed under the terms of the Creative Commons Attribution-

Noncommercial 4.o Unported (CC-BY-NC 4.0) License. http://creativecommons.org/licenses/by-nc/4.0/023 05:36:54AM 
these rights. As the rights of all human beings everywhere, human rights are necessarily universal as a matter of concept, but the universality of the content, i.e. the rights, should be defined and realized through a globally inclusive consensus-building process. All human beings everywhere must therefore contribute to determining the content of the concept of human rights for themselves, and apply them in their own context. This tripartite dynamic is essential for the individual and collective self-determination of the human, the subjects of human rights. To be categorically clear on the point, none of this is up to the choice or discretion of the so-called international community - read former colonial and neocolonial powers. The idea that a group of (Western) states/ societies would define human rights for other states/societies (of the Global South) and then supervise their education in and practice of those rights until they are ready to be trusted with implementing those predetermined norms is precisely 'the civilizing mission' that was alleged to legitimize European colonialism in the $19^{\text {th }}$ century. Since this is the exact antithesis of the universality of human rights, it must be categorically repudiated. The present human rights initiative may succeed or fail, and humanity will continue to strive for life with dignity and justice regardless of the fate of this initiative, but the human rights paradigm cannot exist at all except in terms of the dynamics of globally inclusive concept and content, as realized in local context. There are of course many good policy options and strategies for protecting individual rights and promoting social justice in one setting or another, but none can serve the unique functions of the universality of human rights, as I will explain later.

Before getting into my thesis and argument, I wish to respectfully acknowledge my honor and privilege to pay high tribute to the late Professor Willem Witteveen who was killed with his wife and daughter in the shooting down of Malaysian Airlines flight 17 over the Ukraine on 17 July 2014. Time and space constraints do not permit me to engage his relevant scholarship in this lecture, but I wish to respectfully suggest a significant implication of the tragic death of the Witteveen family in that incident. The brutal reality of that attack illustrates our common human vulnerability, and confirms that to protect human rights anywhere we must strive to protect them everywhere. While our distinguished colleague was striving to promote the rule of humane and enlightened law, he and his family died by arbitrary and cruel lawlessness that was perpetrated within the same geo-political region. The conflict in the Ukraine, which represents a fraction of countless situations of death and suffering of civilian populations in civil conflicts around the world, also demonstrates that human rights should be protected by preempting violations instead of relying on the unlikely and unproductive chance of subsequent accountability. No individual or group of states nor the so-called international community at 
large can ensure accountability of perpetrators after the fact of violation. At the same time, principles of penology confirm that there is little deterrence value, if any, when accountability is unlikely to follow the violation in almost all cases. Preemption of violations should therefore be the primary strategy for the protection of human rights, yet there is no strategy or institutional capacity for preempting violations at the international level.

I am not concerned in this lecture with whether Montesquieu or his ideas as such were responsible or not responsible for European (read throughout this lecture to include North American) imperialism and its impact on the prospects of coherence and efficacy of the modern human rights paradigm. As far as I can see, Montesquieu was a philosopher of his time and context, and could not have foreseen or predicted how his ideas may be read by subsequent generations of Europeans who spearheaded imperialism/colonialism (I use these two terms interchangeably). I am not even concerned with ranking European imperialism/colonialism as unique or exceptional, good or bad in the course of human history at large. My point of departure is simply that Montesquieu's ideas probably contributed to inspiring or reinforcing among European/North American nation-states a self-understanding of being authorized to impose a state-centric, coercive and bureaucratic model of formalistic legality on a global scale. In my view, this state-centric emphasis on formalistic legality is counter-productive for the fulfillment of the universality of human rights as a concept, the realization of inclusive global consensus on the content of these rights and their practical achievements in every context around the world.

Ironically, and despite apparent indications to the contrary, it seems clear to me that the so-called 'civilizing mission' of European imperialism was doomed to fail precisely due to what Montesquieu might call 'Spirit of the Laws' and I see as the paramount human drive to self-determination. Montesquieu's basic insight about the correlation of laws to their respective societies seem to have been anchored in the sort of state-centric legality he envisaged, but I don't see why it cannot apply to other types of normativity known to human societies everywhere beyond the confines of formalistic legality. The rationale of the Spirit of the Laws indicates that it is open up alternative possibilities of what 'law' may mean to different societies, each on its own terms, which means that state-centric anchor of The Spirit of the Laws as such cannot be universal. Despite that inherent relativity, imperial European nation-states seem to have taken the model of state-centric legality as imperative for the realization of the 'public good' in all human societies. In particular, it is the neocolonial application of the imperial fiat of state-centric legality to the protection of human rights that I intend to challenge in this lecture. 
To address these concerns, I will begin by exploring the question whether Montesquieu's political and legal thought may have inspired European powers to seek to impose his models of the nation-state and its positive laws through global colonial projects. This may have been true, I will argue, despite Montesquieu's apparently somewhat contradictory views of The Spirit of the Laws and regardless of his own preference or intentions. He argues that 'laws should be so appropriate to the people for whom they are made that it is very unlikely that the laws of one nation can suit another.' To him, the key to understanding different laws and social systems is to appreciate that they derive from and are adapted to a variety of different factors, including the climate, terrain, way of life, religion, mores and manners, and history of a region or a people. Paradoxically, while he did not quite explicitly say that his views are globally applicable, he did argue that,

[T] here are precepts of natural law that are ethical, scientific and objective that cross cultural boundaries. There are laws and customs relative to geography, time, ethnicity, et cetera--but the laws of nature are general and bind nations together in humanity. Natural law supersedes positivist or secular laws, in which there is a synthesis of general and particular. ${ }^{2}$

Second, I will discuss the structural inadequacy of the current treaty-based state-centric enforcement paradigm while highlighting the accessibility and viability of a universally realistic alternative of cultural transformation and political mobilization for the implementation of consensus-based human rights norms. The proposed paradigm shift will reaffirm the present global reality of inclusive individual and collective self-liberation, which may be the ultimate meaning and purpose of Montesquieu's vision, beyond the limitations of the imagination and experience of his time and location. Once articulated and publicized, ideas assume a life of their own and can be deployed in ways different from the intentions of their authors. Ideas are often modified and adapted in the hearts and minds of other people to serve their own needs and aspirations, which may be beyond the imagination of those who initiated those ideas. Moreover, it seems to me, the appropriation and transformation of ideas is inevitable because the authors could only have thought of and articulated their

1 A.M. Cohler, B.C. Miller and H.S. Stone (eds.), Montesquieu, The Spirit of the Laws (Cambridge University Press 1989) 8.

2 R. Schindler, 'Montesquieu's Political Writings: Selections from Considerations on the Causes of the Greatness of the Romans and Their Decline (1734)' <http://www.rschindler.com/montes quieu.htm> accessed 17 June 2016. 
ideas within the realm of their own circumstances which are unlikely to suit the circumstances of subsequent generations in their own or other societies.

To briefly cite a current example which is particularly relevant to our subject, the framers of the Constitution of the United States, who were clearly influenced by Montesquieu among other philosophers of the European Enlightenment, saw no contradiction between the principle of fundamental constitutional rights and the legal right of citizens to own and dispose of slaves as property. Yet the same Constitution was invoked by the time of the Civil War some eighty years later to require the total emancipation of all slaves, and invoked again during the Civil Rights movement to mandate equal citizenship for descendants of former slaves. On June 26, 2015, the United States Supreme Court ruled in Obergefell v. Hodges that bans on same-sex marriage at the state level are unconstitutional because they violate the Due Process and the Equal Protection clauses of the Fourteenth Amendment of the Constitution of the United States. ${ }^{3}$ None of the framers of the Constitution of the United States could have imagined that the document which came into force in 1789 could possibly be interpreted and applied to those ends.

The third theme of this lecture will be an exploration of the people-centered alternative to the state-centric enforcement model for human rights. To anticipate that analysis, my argument is not simply about replacing an ineffective enforcement model by a more effective cultural and political alternative. Instead, my claim is that the current legalistic, state-centric approach has utterly and totally failed in providing any protection of human rights whatsoever. By calling what I am proposing an 'alternative' in the title of this lecture, I am being courteous to all those who have honestly and earnestly struggled to provide some form or degree of protection of human rights through the totally inappropriate means of the so-called international protection. To put it bluntly, there is no possibility of any form or degree of protection of universal human rights until we devise and establish such a radical reinvention of international law that repudiates the most characteristic features of the current international law system as we know it today. Since state sovereignty and exclusive territorial jurisdiction are the most characteristic features of current international law, the protection of rights will always be limited to civil rights of citizens, not the human rights of all people. Even the International Criminal Court, ${ }^{4}$ as the most

3 Obergefell $v$ Hodges, 135 S Ct 2584 (2015).

4 The Rome Statute of the International Criminal Court, adopted 17 July 1998, and came in force 1 July 2002, United Nations, Treaty Series, vol 2187, No $38544<$ http://treaties.un.org> accessed 16 June 2016. See also the website of the International Criminal Court $<$ https://www .icc-cpi.int/en_menus/icc/Pages/default.aspx> accessed 16 June 2016. 
recent attempt to deal with individual persons as subjects of international law, is doomed to failure, in my view, due to the limitations of state-centric legality among other problems. ${ }^{5}$

2

\section{The Legacy of Montesquieu?}

To say that Montesquieu was a man of his class, gender, time, place, socioeconomic and political context is a statement of fact that does not in the least imply an evaluation of his legacy one way or another. Yet, it is because his influence extended far beyond his immediate context that his legacy is contested among various constituencies which claim his support and sympathy. The question mark in the title of this section is to indicate that his legacy is contested across generations as well as among scholars of the same generation. Although fortunately I don't need to engage the full complexity and nuance of those contestations, it is important to try to highlight aspects which are relevant to my concerns with European imperialism and its colonization of the human rights paradigm in particular.

As stated earlier, my point of departure is simply that Montesquieu's ideas contributed to inspiring or reinforcing a self-understanding among West European nation-states of being authorized to impose a state-centric, coercive and bureaucratic model of formalistic legality on a global scale. In the following brief overview of some of his ideas and competing views of his work for the limited purposes of my claim, I appreciate Witteveen's caution to avoid two pitfalls in reading classical text, namely:

The one is selective quotation, borrowing ideas as authoritative arguments for discussions that should be decided on other grounds. The other is burying ideas in history, explaining everything of enduring interest in a text as part of the outmoded vocabulary and the discursive politics of its time. ${ }^{6}$

It is also wise to remember that, like in any discourse, there is room for varying interpretations of what Montesquieu said or what he meant by what he did say. Indeed, there are explicit textual grounds for differing views of what he

5 A.A. An-Na'im, 'Editorial Note: From the Neocolonial 'Transitional' to Indigenous Formations of Justice' (2013) 7 The International Journal of Transitional Justice 1.

6 W. Witteveen, 'Reading Vico for the School of Law' (2008) 83 Chicago-Kent Law Review 1202. 
intended as I will briefly cite later. Subject to these caveats, here are some of my reflections on some of his relevant ideas and views.

To begin with, I have some concerns about his 'methodology' and style. The Spirit of the Laws is full of the casual prejudice and pseudo-scientific racism of Montesquieu's age. 'Indians are by nature without courage', he noted, explaining that their 'zatrocious actions' and 'barbaric customs' derive from both their natural temperament and their hot climate. ${ }^{7}$ His cursory mingling of examples from various cultures and continents seems to me to reflect the worldview of a highly educated, 18th century European man who never actually travelled to the places he described but rather relied on first-hand accounts by others. He picks examples from Europe, Africa, Asia and the Americas to support his arguments about political liberty, the nature of life under different types of governments, the effects of human nature on laws, the origins of various practices and power structures. His theory is strongly informed by the laws, governance, and politics of classical civilizations, which may reflect his class and the nature of his education. ${ }^{8}$ His book, The Spirit of the Laws, is also infused with Orientalist rhetoric and images. For example, he characterizes African, Middle Eastern and Asian countries as despotic, sensual, timeless, unchanging, marked by a love of luxury, and ruled by passions. ${ }^{9}$ Contrasting European with Turkish (Muslim) monarchies, he said, 'In most kingdoms in Europe, the government is moderate... Among the Turks, where the three [legislative, executive and judicial] powers are united in the person of the sultan, an atrocious despotism reigns. ${ }^{10}$

Montesquieu's writing about slavery seems to indicate a deep ambivalence. His defense of European enslavement of Africans is remarkably offensive, but it is unclear whether he actually endorses this defense, which he presents after stating, 'If I had to defend the right we had of making Negroes slaves, here is what I would say'.1 One might wonder, however, why did Montesquieu accept this task even as a hypothesis in the first place, and why he limited it to Negroes while all races, including Europeans, have been subjected to slavery for much of human history? Parts of the section entitled 'On the slavery of Negroes' are so gratuitously and graphically abusive that it is difficult to see it as a hypothetical case or satire. For example, he declared that those subjected to slavery 'are black from head to toe, and they have such flat noses that it is almost

\begin{tabular}{ll}
\hline 7 & Cohler (n 1) 234. \\
8 & Ibid 167-186. \\
9 & Ibid 283. \\
10 & Ibid 157. \\
11 & Ibid 250.
\end{tabular}


impossible to feel sorry for them.12 ${ }^{12}$ continues to apparently relish his hypothetical defense of slavery by saying: 'It is impossible for us to assume that these people are men because if we assume they were men one would begin to believe that we ourselves were not Christians.13 Whatever this philosopher of the European 'Enlightenment' meant to say in this ambiguous sentence, it is profoundly bigoted and demonizing Africans, inevitably indicative of a 'noble civilizing mandate'.

As a novice reader of Montesquieu, I am struck by the static, deterministic narrative of 'law' as an outcome of such a wide range of factors and causes. I sense a total absence of the human agency of the people who are making these laws - all factors and causes he noted in The Spirit of the Laws, ${ }^{14}$ seem to be 'given', not the product of struggle, strategy or politics. Perhaps this feature of mechanical social engineering in Montesquieu's writings is part of the Enlightenment's urge to find rational patterns of cause-and-effect and coherent systems. It also seems that Montesquieu believed in some form of natural law that should govern everybody on earth. As I see this aspect of his position, Montesquieu believed that a 'true' law exists in the universe but that different groups of people will realize the 'true law' with differing margins of error based on their particularities and diverse natures. What worries me in this process is who is to decide which is the 'true law', who is the judge of which law 'deviates' and how is that to be corrected. The pull of the claim of a universal norm and the push of relative exception to that norm were highlighted by Robert Howse as follows:

Admittedly, Montesquieu attributes some particularities of laws to differences in religious convictions in different societies, but these differences, for Montesquieu, usually amount to 'prejudices' or 'superstition', which are susceptible to being removed as interaction between peoples and individuals increases, whether through commerce, immigration or intermarriage. It is notable that the distinctive domestic laws criticized by Montesquieu as fanatical or against nature tend to be attributed by him to prejudice, not to the kinds of local factors that might explain 'reasonable' differences between laws. These are laws that deserve to be removed even by imperial conquest. ${ }^{15}$

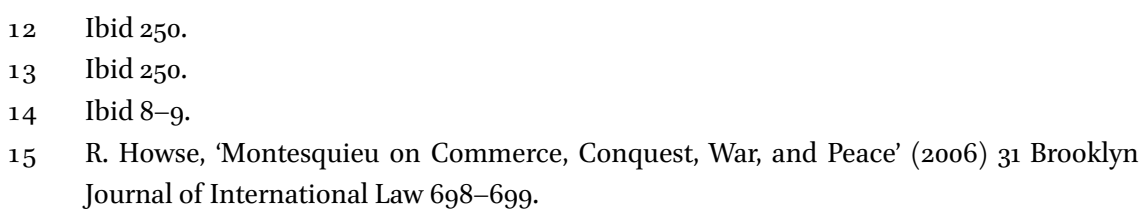


The notion that the 'unreasonable' laws (who decides?) of other people deserve to be removed (by whom?), even by imperial conquest sounds ominously similar to the recent travesty of so-called 'humanitarian intervention' I will repudiate later.

The contributors to a collection of essays, Montesquieu and His Legacy, approach his global-scale analysis of the diversity of laws in light of the contemporary ideal of pluralism. ${ }^{16}$ In the Introduction, Rebecca Kingston highlights a shift in scholarship about Montesquieu's legacy. Expanding beyond the traditional focus on constitutional principles such as separation of powers within Montesquieu's work, scholars have more recently developed an interest in Montesquieu's thinking about the diversity of political communities, as shaped by social norms and customs (or what Montesquieu called 'morals and manners'). One of the themes of Montesquieu and His Legacy as a whole is to explore and celebrate a different intellectual legacy than that often supposed by earlier generations of scholars, who sometimes reduced Montesquieu's intellectual contribution to the concept of separation of powers. ${ }^{17}$ Several authors in this Kingston volume characterize Montesquieu as anti-imperialist. Fred Dallmayr, for instance, observes that Montesquieu's Persian Letters contain warning against foreign adventures and conquests, and especially against policies of colonization. ${ }^{18}$ Michael Mosher also emphasizes Montesquieu's view that empire, colonialism, and despotism were forms of illegitimate rule that flowed from the undesirable circumstances of large-scale polities and rule from a distance. ${ }^{19}$

Kingston, the editor of this book, summarizes a tension that emerges as a key theme throughout several essays:

While some contributors praise his [Montesquieu's] defense of universal justice, an invocation that shapes his injunctions against international aggression and his condemnation of slavery, it is not clear how Montesquieu reconciles this commitment to universalism with his vision of moral pluralism. ${ }^{20}$

16 R.E. Kingston (ed.), Montesquieu and His Legacy (State University of New York Press 2008).

17 Kingston (n 12) 2.

18 F. Dallmayr, 'Montesquieu's Persian Letters' in R.E. Kingston (ed.), Montesquieu and His Legacy (State University of New York Press 2008) 252.

19 M. Mosher, 'What Montesquieu Taught: 'Perfection Does Not Concern Men or Things Universally', in Rebecca E. Kingston (ed.), Montesquieu and His Legacy (State University of New York Press 2008) 8, 26.

$20 \quad$ Kingston $(\mathrm{n} 12) 5$. 
An implicit call for imperial mandate to 'civilize' can be seen in his view:

The true foundation of this approach, he says, is not a proof inherent in the maxims, but more so the proof of the goodness of God, from which men come to see, first the maxims' interest in their well-being, and secondarily, their own interest in following them. Thus, we return to our cannibal with a call to his own interest in order to persuade him to conform to the principles of humanity [my emphasis]..$^{21}$

The implication of the imperial mandate to civilize is in the phrase, 'we return, etc'. Who is the 'we' and how do we 'persuade' the cannibal? What if the cannibal refused to be persuaded? Although he reads Montesquieu as anticolonial and anti-imperial, Michael Mosher finds that he defends 'military intervention on grounds of human rights or even on grounds of the promotion of enlightenment'.22

According to Brian Singer, Montesquieuresists theidea of self-determination. 'The idea that the people could be at the source of the laws, particularly the fundamental laws, is, for Montesquieu, both improbable and dangerous; any such pretension would confuse the power of the people with its liberty (XI, 3), and result in the revolutions born of extreme equality. If De l'Esprit des lois leaves one lasting impression, it is that legislation requires a specialized, prudential knowledge, which should not be left to an untutored and changeable instance like the people.23 This view of Montesquieu is explicitly stated in chapter 3 of book XI of The Spirit of the Laws:

Liberty can consist only in having the power to do what one should want to do and in no way being constrained to do what one should not want to do... Liberty is the right to do everything the laws permit; and if one citizen could do what they [laws] forbid, he will no longer have liberty because the others would likewise have the same power [my emphasis]. ${ }^{24}$

21 W.B. Allen, 'Ethics of Montesquieu: Principle of the Foundation of American Democracy' <http://williambarclayallen.com/articles/Ethics\%20of\%2oMontesquieu.htm> accessed 16 June 2016.

22 M. Mosher, 'Montesquieu on Conquest: Three Cartesian Heroes and Five Good Enough Empires' (2005) 8 Revue Montesquieu 108-109.

23 B. Singer, Montesquieu and the Discovery of the Social (Palgrave Macmillan UK 2013) 151. Singer's reference to $(\mathrm{XI}, 3)$ in this quotation is to the book and chapter of The Spirit of the Laws.

24 Cohler (n 1$) 155$. 
Whatever may be the source of the 'should' and 'permit' of what we are allowed to want, do or not do, it is clear that Montesquieu does not trust people with their own liberty and well-being.

Manjeet Kaur Ramgotra argues that most scholars read Montesquieu as rejecting imperialism and despotism in favor of international, democratic peace, but she interprets Montesquieu's theory in light of commerce and colonialism to argue that his 'fundamental constitution' facilitated expansion and that his ideas were conceived in a context of colonialism and transatlantic slave trade that cannot be divorced from his philosophy. ${ }^{25}$ She reviews various authors to conclude that Montesquieu promotes,

The idea that for the benefits of trade and peace, civilized states were justified in intervening in the less developed nations to assist in their improvement by bringing not only protection but also bringing civil and political laws, and as a result, freedom. ${ }^{26}$

This view of the roots of European and American imperialism resonates with, for instance, from the Opium Wars in China (waged first by Britain in 1839-1842, and second by Britain and France in $185^{6-1860)}$, to the American invasions of Afghanistan and Iraq in 2001 and 2003. Robert Howse presents a similar analysis: 'Montesquieu's remarks about war and conquest in Books IX and $\mathrm{x}$ must be understood in light of his dramatic presentation of a continuously expanding republican federation as the only adequate solution to the problem of politics'. ${ }^{27}$ Howes continues: 'In a remarkable single stroke, Montesquieu endorses the right to conquest as a necessary implication of the right to self-preservation... [albeit subject to] a set of derivative legal constraints on the manner in which the right to conquest may be exercised'.28

One can continue to indefinitely cite opposing arguments and endless series of quotations and counter-quotations from Montesquieu and his scholars, without ever resolving whatever aspect of his influence is at issue. The 'smoking gun' sort of conclusive evidence cannot be found in such matters, and that is probably for the best because the real issue is what people make of such intellectual legacies rather than what historical figures like Montesquieu

25 M.K. Ramgotra, 'Republic and Empire in Montesquieu's Spirit of the Laws' (2014) 42 Millenium - Journal of International Studies 790.

26 Ramgotra (n 21) 795, citing A. Anghie, Imperialism, Sovereignty and the Making of International Law (Cambridge University Press 2005) 96-100 on this point.

27 Howse (n 11) 699.

28 Ibid 700. 
truly intended to say. Regardless of his precise formulations, it seems that Montesquieu, together with other European philosophers of the 'Enlightenment', were taken by European ruling classes to have inspired or legitimized a self-understanding of being authorized to impose their values and policies on the rest of the world. It can also be argued that Montesquieu would have agreed with an imperial European self-understanding since he could not have anticipated the scale and magnitude of the global dynamics which motivate my present self-understanding as an African Muslim to be empowered to resist whatever I do not freely and knowingly accept for myself. It is this liberating self-understanding that I now seek to highlight and vindicate.

\section{Inadequacy of Legal Enforcement of International Human Rights}

It is probably only a slight exaggeration to say that human rights treaties are orphans, born and abandoned in a hostile and reckless environment, attracting the attention of predators more than defenders. The reason for this sad situation is integral to international law itself and how it is supposed to work regarding treaties. The underlying assumption of the international law of treaties is that states negotiate, adopt, ratify and implement treaties to serve their own self-interests, including their effort to minimize obligations and evade responsibilities, a sort of normative 'buyer beware'. This assumption works best where powerful states are keen on the enforcement of the international obligations of states party to a treaty dealing with material or security interests of states, which is not likely to be perceived to be the case for human rights treaties. Although the protection of human rights ought to be in the self-interest of states, none of the present states is willing to act accordingly, at least not at the expense of what they perceive to be their sovereign autonomy and domestic political stability. Later in this section of the lecture, I will explain various aspects of the normative and practical limitations of the international protection of human rights, but let me first clarify the scope of my critique.

The ancient practice of respecting or protecting some basic entitlements, not traditionally called rights, which are necessary for the preservation of life, dignity and related concerns exists in all human societies, albeit articulated and practiced in distinctively contextual ways. Such organic, indigenous social and political strategies will no doubt continue regardless of what political philosophers and jurists say, and whatever states do or fail to do. The recent shift to the protection of those entitlements in terms of fundamental constitutional rights in the context of modern liberal states must also continue as an adaptation of ancient traditional process to the context of modern nation 
states, and also expand to protect more entitlements of human beings who are subject to jurisdiction of the modern nation state. I fully support such varieties of the protection of entitlements of human beings to life, dignity and related concerns, and expect them to constitute an integral part of the alternative approach to the protection of human rights I am proposing below.

The establishment and development of human rights as due to all human beings by virtue of their humanity and without any kind of distinction under the Charter of the United Nations of 1945 and the Universal Declaration of Human Rights (UDHR) seeks to achieve the benefits of constitutional entrenchment of certain rights beyond the contingencies of national politics. That is, these founding documents initiated the process of internationalization of the principle of constitutional rights to apply globally as entrenched rights to be protected against abrogation by the government of the day, even with the support of the strong majority of the population.

What is distinctive about the human rights paradigm since the Charter of the United Nations of 1945 , is that it seeks to protect the rights of all human beings, everywhere and all the time, regardless of any quality or qualification other than being human. To fulfill its mandate and rationale, this most recent and radical conception of the entitlements of all human beings should not be limited by or dependent upon the good will of any so-called nation state, group of states or an international organization, or limited to members of any group, like citizens of a state or any sort of affiliation short of the totality of humanity at large. This is the core meaning of universality of human rights, namely, that they are the rights of every single human being without any distinction or discrimination for any reason whatsoever, and regardless of whatever view we may have about what these specific rights may be. In fact, people will probably continue to disagree for ideological, cultural, religious or other reasons about what I called earlier the content of the concept, but no claim qualifies for being a human right unless it is the right of every single human being without any distinction or discrimination for any reason.

Failure to achieve this core meaning of universality is the incurable fault of the present state-centric international human rights system, premised on international law which is founded on the territorial sovereignty and exclusive domestic jurisdiction of nation states. As the only full and autonomous subjects of international law, only states can have rights and obligations under that system, and only states can claim rights and discharge obligations under that system. Individual human beings and their communities are said to be the purported beneficiaries of human rights, but those rights cannot vest in or be claimed by individuals or communities except through the agency of their states. Consider the following legal principles and operational realities 
of international law to appreciate the complete inadequacy of the claim of international protection of human rights:

- Customary international law is made through general and consistent practice of states out of a sense of legal obligation, which is extremely difficult to prove for affirmative human rights norms among all states, and impossible for states which refuse to abide by the norm in question. General state practice out of a sense of legal obligation in support of freedom of speech is impossible to find for a state which prefers to impose strict limitations on this human right.

- Only states can be full parties to international human rights treaties, which they are free to join or refrain from joining, as well as to limit or qualify their obligations under all treaties, via reservations, declarations, and understandings.

- International organizations may now be parties to treaties with states, but that is unlikely to influence the protection of the right against states for several reasons, including lack of powers or resources to act without authorization by member states acting through the institutions of the organization, and lack of access to the territory or population without the consent of the same state which is suspected of perpetrating human rights violations.

- As sovereign holders of exclusive jurisdiction over their own territories and populations, states cannot be forced to cooperate with other states or international organizations unless required to do so by the Security Council of the United Nations acting under the limited and specific requirements of Chapter viI of the Charter of the UN.

In short, states cannot be compelled to assume international obligations to protect human rights even of their own citizens, and cannot be coerced into discharging whatever human rights obligations they have assumed under customary international law or treaties.

Confronted with the profound inadequacy of international law for the enforcement of human rights through international law, major Western powers have resumed their old colonial practices under the guise of so-called humanitarian intervention. This aggressive imperial conduct not only violates fundamental principles of the Charter of the United Nations as a universally ratified constitutional treaty, but in fact repudiates the idea of the rule of law in international relations. In practice, moreover, such reckless and irresponsible behavior is incapable of achieving sustainable protection of human rights for the vast majority of the population on the ground. The intervening powers cannot stay long enough to transform the political and legal institutions of the state, 
and their conduct cannot inspire the confidence and cooperation of local populations. In Afghanistan, for instance, American administration personnel and troops do not speak native languages or have any cultural competency to interact with the general population: they cannot live with Afghan families at home to protect their women against their men, accompany girls back and forth to schools. It is not surprising therefore that pretensions of humanitarian intervention have totally and consistently failed in every single instance it was alleged. The only success such savage behavior of the major Western powers can hope to achieve is to irredeemably associate human rights with historical colonialism and current imperial aggression.

\section{4}

\section{An Alternative People-Centered Implementation Approach}

I opened this lecture with a strong claim about the universality of human rights in terms of the concept, content and context of these rights. As the rights of all human beings everywhere, human rights are necessarily universal as a matter of concept, but the universality of the content of the concept, i.e. the actual rights, can only be realized through a globally inclusive consensusbuilding process. The premise of the self-determination of every human subject of these rights everywhere requires the active role of all human beings in implementing these rights for themselves in their own context. I also posited the categorical claim that the human rights paradigm cannot exist at all except in terms of the dynamics of globally inclusive concept and content, as realized by the human subject in local context. Whatever is done by other means may be good policy for protecting individual rights and promoting social justice for some people as citizens of a particular state and within the territorial jurisdiction of that state. But none of that can achieve the fundamental selfliberation human beings can realize and sustain for themselves through the human rights paradigm.

As emphasized earlier, the significant difference is that constitutional rights at the national level are due only to the citizens of the particular state, whereas human rights are due to all human beings everywhere. Yet, while set as the 'common standard of achievement for all peoples and nations', according to the Preamble of the UDHR, universal human rights can only be implemented in practice through national constitutional and legal systems. Human rights treaties and institutions that have evolved since 1945 seek to implement the universality of human rights, but they can only do so through national systems. Unfortunately, enforcement of human rights through international law is unworkable either, as explained in the preceding section. This brings me to 
the final step in my analysis, namely, the search for alternative strategies for the protection of human rights. The alternative I am proposing would first acknowledge and affirm any form or degree of protection of human rights that can be achieved by any means, including international enforcement to the extent it can work. Second, the approach I am proposing of cultural transformation and political mobilization is already working with whatever approach we use. To enhance the desirability of the proposed emphasis on non-enforcement methods, we need to highlight its limitations or inhibiting factors, especially what I call the dual paradox of the human rights paradigm.

The first paradox is that, while it is imperative to uphold and protect human rights throughout the world, the universality of these rights cannot be assumed nor simply proclaimed. Since all human societies adhere to their own normative systems, which are necessarily shaped by their particular context and experiences, any universal concept is by definition a construct or hypothesis that cannot be simply proclaimed or taken as given. Human beings know and experience the world as themselves, men or women, African or European, Christian, Muslim or Hindu, rich or poor. The consciousness, values and behavior of human beings everywhere are partly shaped by their local cultural and religious traditions. The quality of being a universal norm can therefore only be achieved through a global consensus-building process, and neither assumed nor imposed through the hegemony of universalizing claims from one relativist perspective or another.

As I have argued elsewhere, ${ }^{29}$ this paradox can and should be mediated and negotiated through practice over time, rather than expected to be resolved once and for all. The notion of mediation is used here to emphasize that the tension remains, while the idea of negotiation indicates the multiplicity of authorship and contributions from a variety of perspectives. The underlying principle of equality and non-discrimination includes the right to be different, as people do not abandon their distinctive identity and religious or philosophical beliefs in order to qualify for human rights, but claim these rights as the persons they are and through their own experiences. ${ }^{30}$ The challenge is therefore how to promote and sustain consensus on universal human rights

29 See, for example: A.A. An-Na'im (ed.), Human Rights in Cross-Cultural Perspectives: Quest for Consensus (University of Pennsylvania Press 1992); A.A. An-Na'im, 'Cultural Transformation and Normative Consensus on the Best Interest of the Child' (1994) 8 International Journal of Law and the Family 62; and A.A. An-Na'im, 'The Contingent Universality of Human Rights: The Case of Freedom of Expression in African and Islamic Contexts' (1997) 10 Emory International Law Review 29.

A. Sachs, Advancing Human Rights in South Africa (Oxford University Press 1992), ix. 
norms despite the permanence of difference among persons and cultures. To avoid misunderstanding, my purpose in raising this challenge is to affirm and realize the universality of human rights, as a practical principle of policy for all societies, rather than questioning its paramount importance.

The present system and processes by which human rights are supposed to be implemented are premised on the traditional view that rights are to be understood and realized under a specific political or legal system, and understood within a particular religious/cultural frame of reference. The tension between the universality of human rights and citizenship stems from their complex relationship with the European model of the territorial state with exclusive sovereignty and jurisdiction which came to prevail throughout the world through colonialism. ${ }^{31}$ This model of the state has also been incorporated into international law, which is the legal framework for the protection of human rights under the UN and other regional systems. Universal human rights are legally binding on states because they are provided for in treaties under international law, yet these obligations are supposed to be implemented by sovereign states within their own exclusive territorial jurisdiction. But since territorial sovereignty precludes intervention in the 'internal affairs of states' (Article 2 (7) of the UN Charter), the paradoxical result is that states are entrusted with the implementation of international standards within their own borders. As a framework for international cooperation in the protection of human rights, the present system also relies on the willingness of states to hold each other accountable for their human rights failures, often at some economic, political, security or other risk to their own national interests.

This paradox is real because the violation or protection of human rights necessarily happens within the geographical and legal jurisdiction of one state or another, yet the principle of sovereignty and territorial integrity of the state preclude external intervention to protect human rights without the consent and cooperation of the state itself. Moreover, since pressure by external actors is difficult to sustain, and is often counter-productive, it is ultimately up to citizens to hold officials of the state accountable for any violation that may occur. It is also citizens who can ensure the adoption of appropriate policies and provision of necessary resources by the state for broader implementation of human rights norms. The ultimate measure of success is for human rights to be routinely respected and protected in the first place, as well as ensuring that effective accountability immediately follows whenever a violation occurs. In both aspects, in the final analysis, it is citizens acting through a variety of 
strategies and levels, who can ensure systematic and sustainable protection of human rights.

To briefly explain, official human rights practitioners at the governmental and inter-governmental level as well as civil society advocates tend to do their work in a piecemeal and reactive manner, responding to human rights violations after they occur, rather than preempting them or preventing their occurrence in the first place. Monitoring and advocacy systems also tend to focus on specific cases, or at best limited issues, in order to be effective in the short term, without attempting to address structural or root causes of human rights violations or creating institutional mechanisms for sustainable respect for and protection of rights. When violations are publicized, the assumption is that other governments are not only willing to risk their national interests in pressuring offending governments, but also have an effective way to exert such pressure. The complexity and contingency of foreign policy objectives and shifting priorities of all governments often preclude reliable prediction of whether any government will act, when and in what ways. It is also difficult to achieve sustainable change without the willingness of other governments to stay focused on the specific situation long enough for results to be achieved.

The second human rights paradox of self-regulation by the state indicated earlier has always been true of the protection of constitutional rights in national settings. Whenever national constitutions provide for entrenched fundamental rights against abuse or excess of power by the state, the authority and power to enforce those rights remains with the state. That paradox has traditionally been mediated at the national level by the emergence of strong local civil society organizations which are willing and able to use domestic legal institutions and political processes to force governments to comply. Domestic civil society organizations and public opinion at large must also be willing and able to act in a similar manner in relation to these universal norms. Since external human rights defenders cannot be at the sites of violations long enough, with sufficient resources, understanding of the local situation and ability to achieve sustainable change, the most viable strategy in my view is to invest in empowering local actors to protect their own rights.

This view does not prescribe a particular set of activities for all human rights actors in every situation, or necessarily exclude various strategies. My point is that the degree and quality of empowering local actors to protect their own human rights should be the underlying criterion for evaluating all activities and strategies because this is consistent with the rationale of human rights in the first place. The human dignity of every person should be upheld by his or her own agency, instead of being dependent on the goodwill of others, which is often doubtful or mixed with their own interests. This means that the focus 
of human rights implementation should be more 'people-centered' and less dependent on the ambiguities and contingencies of inter-governmental relations. ${ }^{32}$ Realistically, it will remain necessary for all governmental and nongovernmental actors to maintain the highest possible level of monitoring and advocacy for the protection of the human rights of all, everywhere, because victims are usually unable to assert their own rights effectively. But the objective must be to gradually diminish such dependency on external protection. ${ }^{33}$

I am not suggesting that victims of torture or gender-based violence should reject efforts by others to end their suffering. Victims would properly welcome immediate relief from any source at any cost. My point is that relief from any source at any cost is ultimately at the cost the human dignity and freedom of victims unless their own agency and self-determination are respected in the process. Conversely, perpetrators of human rights violations seek to undermine the human dignity and self-determination of victims. This lecture is about mediating this paradox, to ensure that human dignity and self-determination of victims are always upheld in all efforts to protect and respect human rights norms. Victims must always be human agents in the protection of their own rights, not mere subjects or beneficiaries. This does not mean that they always protect their human rights entirely on their own, but they should progressively and proactively always be the primary decision-makers and agents of change. I am calling for the deliberate use of the 'space' provided by short term relief to strengthen our convictions and enhance our moral courage to stand by our human rights for ourselves.

To summarize in conclusion, European powers which controlled the UN during the first few decades of the existence of the Organization limited the basis and application of human rights to an enforcement model under statecentric international law, i.e. human rights norms as obligations of states under 'legally binding' international treaties or customary law. The false imperial assumption was that all states are true copies of the European model, and will therefore comply with human rights as legal obligations through international organizations like the UN and its agencies, etc. The enforcement model is

32 A.A. An-Na'im, 'Expanding the Limits of Imagination: Human Rights from a Participatory Approach to New Multilateralism' in Michael G. Schecter (ed.), Innovation in Multilateralism (United Nations University Press 1998), 205.

33 A.A. An-Na'im, 'Introduction: Expanding Legal Protection of Human Rights in African Context' in A.A. An-Na'im (ed.), Human Rights under African Constitutions: Realizing the Promise for Ourselves (University of Pennsylvania Press 2002), 1; and A.A. An-Na'im, 'Human Rights in the Arab World: A Regional Perspective' (2001) 23 Human Rights Quarterly 701. 
trapped in tactical maneuvers of inter-governmental power politics, and has utterly failed to protect the actual human rights of people throughout the world. I will therefore argue for a restoration and rejuvenation of the original model of the cultural transformation and political mobilization approach of the Universal Declaration, which was hijacked and frustrated by states. There will still be a role for state obligations to enact laws, adopt policies, allocate material and human resources, etc., but that will be through cultural transformation and political mobilization, for each society in its own voice and context.

Montesquieu's thoughts on state and positive law provided the impetus for the rise of European imperialism based on those ideas as universal claims, i.e. the global civilizing mission of the White Man. Whether or not Montesquieu himself claimed universality of his ideas of law and governance, the question is whether those ideas were taken by European elites as universally imperative for human civilization. Did the coherence and potency of Montesquieu's theories contribute (not necessarily by his instigation or suggestion) to the rationalization of European imperial ambitions under the guise of 'civilizing mission'? Regardless of the coherence and profound influence of Montesquieu's theories among the European and American societies which inspired those theories and choose to implement them, those theories could not possibly have been or become universal simply because of the historical reality of self-determination in cultural and normative terms far beyond its recent application in decolonization during the second half of the 2 oth century. The fact that human beings everywhere and throughout history have always actually practiced self-determination (under whatever name or no name) to devise their own normative systems and governance structures, means that none of them would have adopted the theories of a European aristocrat over their own. The pretentions of major powers to intervene militarily in other countries in the name of protecting human rights are in fact the greatest deliberately perpetrated gross and massive violations without any prospects of success in protecting any rights whatsoever. 